\title{
11 \\ HOW SCOTTISH IS THE SCOTTISH \\ CURRICULUM?
}

And does it matter?

\author{
Cameron Harrison
}

(I)t is to the advantage of England that the Welsh should continue to be Welsh, the Scots Scots and the Irish Irish.... There may be some advantage to other peoples in the English continuing to be English.... If the other cultures of the British Isles were wholly superseded by English culture, English culture would disappear too.

(T.S.Eliot, 'Notes towards the definition of culture')

\section{NATIONAL IDENTITY AND THE CURRICULUM}

This chapter reflects on the nature, content and structure of the Scottish school curriculum in order to illustrate aspects of the important relationship between national identity and national school curriculum. It is not a systematic description of the overall pattern of the Scottish school curriculum: the reader must seek such a description elsewhere (for example Harrison 1994). Rather, this chapter is an exploration of aspects of the relationship between national culture and national identity: in a Scottish context, certainly, but, I hope, pointing to issues of relevance to educators in all nations.

One important point must be made at the outset. It relates to the notion, central to this chapter, of national identity. I cannot emphasise too strongly that, when I use this expression, I do not refer to any narrow notion of group identity, let alone superiority, asserted in political or ethnic terms. The identity of a people lies in its culture, not in its gene pool. And therein lies the significance of the issue at the heart of this chapter: since, if the matter of national identity is to be understood in cultural terms, then the role of the nation's education system in shaping and forming that culture becomes a matter of considerable importance. It becomes a matter of vital concern to understand the ways in which aspects of the national milieu are reflected in, and consequently shaped by, the education of the nation's young people.

The education of the young is the fulfilment of the covenant between generations. It is in the provision of education that we offer to our young people the best that we ourselves have garnered from our fathers. We introduce to them the knowledge and ideas which have illuminated and enriched our lives: we seek 
to develop in them the skills and capabilities which we have learned are of use, and which have given us our present quality of life; we offer them the best of our values and beliefs, and hope that they will surpass us in the task of living in the light of them; and we do all of this in a process which we hope will deepen their understanding and enlarge their humanity. We call this process education, and we set up schools and employ teachers to put it into effect.

Education, then, is concerned with the transmission of culture and of capability; with the development of the individual, and with a sense of belonging; and the school curriculum is the vehicle for this process. The school curriculum is the answer to the questions, 'What should go on in schools?' and 'What should children learn?' And so the nature and the content of the curriculum matters. It reflects the values and priorities of the nation and it helps to shape the nation's future. To say this is not to ignore the failure of attempts at using schooling as short-term social engineering - that is a different issue: it is to acknowledge the power of ideas and ideals on the minds and lives of the young. Nor is an assertion of the importance of the school curriculum a pretence that there are no other significant influences at work shaping the lives and futures of our young people. It is simply to point to its relative importance in the complex dynamic of forces at work in this arena-and not always at work for the best. For we cannot claim that the influence of schools and of the curriculum on our young people is always an unqualified good.

If there are in this country too many people who fear what is new, believe the difficult to be impossible, draw back from responsibility, and afford established authority and tradition an exaggerated respect, we can reasonably look for an explanation in the institutions that moulded them.

(Smout 1987:229)

\section{CULTURE AND CAPABILITY}

One of the principal roles of an education system, then, is to transmit culture and capability through the generations. The bulk of this chapter considers the relationship between more conventional views of culture and curriculum. Let me, first, give some attention to the notion of capability as an aspect of culture, and to the relationship between each and the curriculum.

The material wealth of a nation, and the quality of life of its people, are heavily dependent on the capacity of its people to create wealth. But such a capability is not simply a matter of possessing a technically skilled workforce; there is also the question of human disposition. The stunning explosion of industry in Scotland in the nineteenth century was a product of many factors. Some were certainly geographical, some geological; some were economic, some political: but one of the most critical factors was the existence, to an extent equalled in few other nations in the world at that time, of a broad sector of welleducated, capable men ready and eager to play their part in this revolution. And 
it is important not to underestimate the importance of that word, eager; because their willingness to act was just as important as was their capacity to do so. The national culture and the national education system had combined in Scotland to produce a substantial tranche of men who valued both presbyteries and profits (Marshall 1992). Because of their education and their theology - and the two were closely linked - these men possessed both the abilities and the disposition to create wealth. And they did. Living and working in a society which did not simply value the acquisition of knowledge and skills, hard work and commitment, but which, through church and school, made the creation of wealth not simply possible but a moral imperative, these men, supported, and sometimes driven, by their womenfolk, 'redeemed the time, because the days were evil!' And in the exceptionally unlikely economic soil of this poor part of a peripheral island, they made the desert to bloom.

There is a general lesson here. Porter (1990) asks a telling question:

Why do some social groups, economic institutions, and nations advance and prosper in international economic competition-and others fail?

And he answers:

the most important aspects are attitudes towards authority, norms of interpersonal interaction, attitudes of workers towards management and vice versa, social norms of individualistic or group behaviour and professional standards... These in turn grow out of the education system, social and religious history, family structures, and many other intangible but unique national conditions.

The relevance of the point, and therefore the importance of the issue, is, I think, self-evident.

\section{HOW SCOTTISH IS THE SCOTTISH CURRICULUM...}

Back, then, to the issues central to this chapter. I want to address this question in three ways. First, I examine the Scottishness of the content of the curriculum; second, I look at its nature, the educational ideas and concepts used, often implicitly, but always powerfully, to frame, design and describe the curriculum for teachers and for schools; and third, and briefly, I describe the nature of the national change and development processes themselves-the characteristic manner in which the curriculum is developed.

\section{...IN ITS CONTENT?}

One of the principal purposes of education is to help young people make sense of their society, to understand why it is the way it is, and to reconstruct from where have come those values and norms which underpin the expectations and patterns of behaviour which are part of their everyday life. If young people are to be able 
to understand who they are, if they are to make sense of the context and communities in which they live, they must have an opportunity to understand the cultural soil from which they have sprung.

\section{Language and literature}

The starting point for any such discussion must surely be a consideration of the place of both Gaelic and Scots language and literature in our schools. It is important to begin on a positive note. That is because, while few would deny that much has been done in recent years to help support and enlarge the place of both these areas of the school curriculum, many would argue that such current attention no more than begins to make up for the neglect, indeed active persecution, which these areas suffered in the past. That may be so; nevertheless, it is important to note that the age of hostility is past. The current debate recognises the importance of these matters; at issue now is only the nature and extent of the support to be given - determining the best way forward.

But, even given the positive steps taken in recent years, there are those who remain sceptical about the desirability of such actions. Their queries, too, are important and deserve respect. 'Why preserve a faltering language?', they ask. Or even, 'Why attempt to revive a dying one?' These questions demand sound answers - especially in a time of economic stringency and curriculum overload.

And such questioners have a point: without doubt, problems do exist. For example, current writing in Scots, and to a slightly lesser extent in Gaelic, is of mainly one sort: it is expressive, rather than transactional or discursive. In both tongues our poetry is flourishing and our creative writing and story-telling are acquiring a new life. There are, however, no parallel developments in the broader fields of writings about ideas. No one is writing about economics in Scots: there are no Ph.D. theses in physics being crafted in Gaelic. The volumes in the excellent New History of Scotland series (1992) are written (much to the surprise of my Dutch friends) not in Scots, but in English, and (to their utter astonishment) no one in Scotland even seems to regard that fact as worthy of notice, let alone regret. Why is this so? The reason is not, as some have asserted, that either of our native tongues is in some way deficient or inadequate in the language of discourse. No, the reason is much simpler, much more powerful and, sadly, much more inexorable. The lifeblood of intellectual growth and the development of ideas is the process of discourse. The exchange of ideas, debate, challenge, agreement, dissension, consensus all require an appropriate vehicle for communication and access to a wide audience. In medieval Christendom the vehicle was Latin; in our time it is English.

Scotland, of course, has both benefited and suffered from its close linguistic ties with England. We have benefited in that we are able to piggy-back on the international currency of our near neighbour's language and its rich literatureand being so closely related to Scots, at least it is eminently accessible to us. 
Would Walter Scott have had the phenomenal effect on European culture and literature which he has if he had been writing in Gaelic? I fear not.

But there is a corresponding disadvantage to our close linguistic relationship. If our language had been more significantly different from English, perhaps the seventeenth century would have seen a Scots Bible, as it saw a Welsh one. That one step would have made such a difference. As it was, the inexorable pressure mounted-remember that Davie Hume died confessing not his sins but his Scotticisms - and now we are faced with the formidable task of restoring not only to currency, but to respectability, a tongue which has for generations been presented in public as the language of the comedic, the nostalgic or the hopelessly maudlin. Frankly, our Gaelic cousins have in many respects an easier task.

The case for despondency is not overwhelming, however. That is because, in an interesting irony, the forces of history may be on the side of threatened, minority languages. All over the world-excepting, of course, in the United Kingdom and former colonies - the power and pervasiveness of the English language are working a change. The youth of nation after nation is, both by national educational policy and by the ease of international communication, becoming bilingual. Nor, by and large, is this seen in most developed countries as a threat (set aside France for the moment), but as a political, cultural and economic necessity - for the youth, indeed, it is often fait accompli. Across Europe, governments and educators see both the importance and the advantages of the adoption of English and the vital importance of preserving their own tongues. Last year, the Netherlands Parliament was within a whisker of passing a law insisting that in future all, as opposed to most at present, instruction in science in their upper-secondary schools should be in English. But at the same time they insist on providing for linguistic diversity even within their own small country - the Friesians of north Zeeland are consistently and powerfully supported by their national government in their own language not only as a legitimate subject of study, but also as a medium of instruction. A recent encounter with thirteen leading figures from the national education system in Albania revealed that all of them had read Ivanhoe, in English, at school. Rob Roy too, even before the film, was a 'weel kent cheil in Albanian schools; though whit they made of Andra Fairservice I'd like fine tae ken!'.

All over the developed and developing world the same trend is evident: linguistic confidence is reflected in an eagerness to carry forward national tongues and, at the same time, gain access to the advantages of the new international lingua franca-English.

But perhaps the history of language in Scotland holds lessons for all nations world-wide. Perhaps the international drift towards English in academic discourse, in science and technology and in business and commerce really does present long-term challenges to non-English-speaking nations. Perhaps, even more, the growing dominance of English in the field of entertainment and in the increasing permeation of the Internet both as a means of communication and as a 
medium of distribution presents not just challenges but threats to local linguistically framed lines of cultural and literary heritage. The lesson from Scotland is certainly that this can be the case-but that it need not be so. Although we were dangerously late to act, our experience is that national language and literature can flourish alongside English; and that in doing so, they can enrich and illuminate the lives of a country's young people. But to ensure that this happens, we have found, does require active curriculum planning on the part of schools - and real support nationally in the form of advice and resources. The key to tackling this problem is a confident realisation that defence against the powerful and pervasive effect of international English is neither possible nor, probably, desirable; but that active and appropriate intervention can ensure parallel language development; and that in this way the curriculum, and thus the culture, of the nation will be enriched and not impoverished.

\section{History and society}

How can young people growing up in Scotland understand their society, or indeed their environment, without knowing of the forces, from within and from without, which have shaped our poor and privileged nation: our brotherhood and our enmity with our southern neighbours; our periods of war and our times of peace; our rough wooings and our eventual contract of marriage? How can our young people understand the society of which they are part unless they have opportunity to understand the forces which have formed it? They live in a society shaped by theology and by industry, by prophets and by profits. Why do these grand gothic Victorian churches stand at every street corner of wealthy west end city suburbs - and why two church buildings, if seldom now two congregations, in hundreds of tiny villages up and down our country? What did the Scottish Enlightenment do to world thought and what did it do to the poor Scots tongue? Why do Glasgow, Edinburgh and Dundee all have two major football teams (pace the Jags!) and Aberdeen only one? What circumstances led to Scotland's transformation from a kind of medieval Albania to having one of the highest, if not the highest, per capita incomes in the world by the last quarter of the nineteenth century? What processes, at home and abroad, have taken Scotland, tiny Scotland, from being the place where, at the turn of the century, half the world's shipping and a third of its locomotives were being manufactured to where we are today - a country with no steel industry, though a promising silicone one? How did it happen that, in the early part of this century, and all over the world, the words 'quality 'and 'reliability' conjured up to the world an image not of Japanese motor cars but of Scottish ships? What on earth has happened since?

The opportunity to develop such understanding demands a central place for history, and for Scottish history within the curriculum. But not just any Scottish history. A history which is comprehensive, in that it reflects all the major events and processes which shaped our nation and our society. A history which is both a 
vehicle for the education and development of the individual and, as importantly, offers the information and ideas which will allow those young people to make sense of who they are and of their society. Not a 'here's tae us' history, celebrating the undoubted, indeed astonishingly disproportionate, contribution of this small nation of ours to modern thought and achievement; but a history which seeks to understand equally our successes and our failures, our triumphs and our guilt. Not an exclusive, scotocentric view of history, but a history which, having established a sense of process and chronology, having told the whole broad tale, constantly sets local and national events and processes in the context of, and connects them to, events and processes in the rest of Europe and the rest of the world.

\section{...IN ITS NATURE?}

It is not just in its content that our school curriculum is Scottish. It is also characteristically Scottish in its design. One of the striking facts which emerge when the Scottish school curriculum is compared with that in any other part of the United Kingdom is that it appears to be constructed with reference to different design principles. For example, in Scotland, where a child-centred educational philosophy was adopted more cautiously, though perhaps ultimately more thoroughly, than in England, the primary-school curriculum is organised in broad 'curricular areas'; in England it is organised in subjects. That difference respects a conviction in Scotland, slowly acquired but now firmly held, that it is important for the curriculum, and the process of learning, to respect the child's experience and view of the world (see Chapter 3 ).

I want to point to two other significant differences in the way in which the Scottish curriculum is constructed. I have chosen these areas not just because they are important in their own right but because they reflect significant aspects of our culture and of our evolving beliefs about education.

\section{Breadth and balance}

The first is the issue of breadth and balance in the curriculum. Now, breadth and balance are matters which have become almost a shibboleth in Scottish education. Scots generally assert that our school curriculum discourages narrow specialisation - especially in comparison with most other parts of the United Kingdom. We claim adherence to the broad liberal ideal, and insist on breadth of experience and on coverage in the curriculum of all important areas. In some respects, of course, we live up to this ideal. Thanks mainly to the Munn committee (SED 1977) of the mid 1970s, to the efforts of the Scottish CCC since, and, crucially, to the support of HM Inspectorate, Scottish curriculum guidelines for primary and for secondary education to age sixteen currently ensure that a significant measure of breadth and balance in the curriculum is experienced by all our young people. However, not everything in the garden of the curriculum is 
rosy. The Howie Report (SOED 1992) on the future of upper-secondary education in Scotland came in for a good deal of sharp criticism in certain crucial aspects. Its ill-thought-through proposal to divide young people into two streams, academic and vocational, met, quite correctly in my view, with overwhelming rejection. But in one other regard Howie launched a devastating critique of our present system - one which has not received the attention it deserved. The issue is that of breadth and balance within the area of the fifth- and sixth-year school curriculum. The committee had two main lines of criticism. First it pointed out that there was a great deal more narrow specialisation amongst students taking Highers than we were pretending. English, mathematics, physics, chemistry and biology was a not uncommon groupingparticularly amongst certain sectors of students. On the other hand variations on the English, history, geography, French and German theme were far from infrequent. Worse than that: comparing our upper-school curriculum with that of our continental neighbours, Howie launched a devastating attack on our very concept of breadth. We had no answer.

So how Scottish is the Scottish curriculum in this regard? Compared with the English ours is very Scottish - if that isn't Irish. But compared with our own aspirations - not to say our liberal traditions and former good practice-we are weighed in the balance and found wanting.

\section{Academic and vocational}

Which brings me to my second point. I return to Howie's concern to 'bridge the academic-vocational divide': to 'create parity of esteem between academic and vocational courses'. This is an exceptionally interesting issue: it illustrates sharply the importance of keeping a canny ee on the ideas we use as the coinage of our thought - particularly as we try to frame a problem. Let me borrow an example from higher education in order to illustrate what I mean.

Two years ago, my son-like so many other young reprobates before himcompleted an honours degree in law at Edinburgh University. Now, was that an academic or a vocational course? The answer is, of course, 'Yes! - that course is highly academic and highly vocational.' Whence came this idea that vocational and academic qualities are dichotomous? The university Scot of the nineteenth century would have stared in incomprehension at anyone who voiced such ideas. Learning in Scottish universities then was highly academic - in the sense that the knowledge was pursued rigorously, objectively and, if necessary, for its own sake. And this was done in the context of institutions and courses which were very highly vocationally focused (Walker 1994). The two aspects of life and of learning were seen as being of equal value and, as important, as being both coexistent and interlinked.

The same age, which produces great philosophers, and politicians, renowned generals and poets, usually abounds with skillful weavers and ship 
carpenters. We cannot reasonably expect, that a piece of woolen cloth will be brought to perfection in a nation, which is ignorant of astronomy, or where ethics are neglected.

(David Hume in Scott (1993))

From where has this misleading idea come, then - this notion of the academic being an exclusive alternative to the vocational? The answer to this question, regrettably, does not reflect well on the Scots. The hollow, but disabling, vocational/academic controversy is a straightforward reflection of a very classspecific value system which was not native to Scottish culture, but which has been enthusiastically imported by sections of our aspiring social elite. The vocational/academic schism reflects another nation's system in which, in relatively modem times, the two great universities served primarily as finishing schools for the gentry. At the same time in Scotland, the ancient universities, while probably sustaining higher academic standards, were unashamedly vocational. They were the pathway into the professions: law, medicine and the church - and for the 'sticket', there was always teaching. In England the oldest universities, and the exclusive, expensive, private schools, served as both the guardians of privilege and as gateways for the aspiring upwardly mobile-at least those who could afford the price of entry. They were a port of entry to respectability, to a stratum of society where the very worst sin was to earn your own living. The archetypal product of this system was the effortlessly accomplished amateur, with no visible means of support and a contempt for anything useful — in art or in life. We see the powerful, and damaging, inheritance of that value system still today in what Hutton (1995) calls the rentier society - the gentlemanly capitalists - the present-day elite of our system. And this false academic/vocational dichotomy has, I regret to say, become a British, and not simply an English, trait. The impact is evident in our own society and our own education system.

How Scottish is the Scottish curriculum? It pains me to say so, but we Scots have fallen from grace - and in a most uncharacteristic manner. We have failed to examine and question the ideas we have been using to shape our thoughts and our actions. It will not be easy to recover this lost ground.

\section{...IN THE PROCESSES ADOPTED TO PRODUCE AND DEFINE IT?}

There is a third sense in which the question 'How Scottish is the Scottish curriculum?' can be asked: it focuses upon the method by which national guidelines for the school curriculum are produced. This may at first glance seem to be a peripheral issue; in fact it is central to the main point.

A range of factors have shaped Scottish practice in developing national guidelines. Key amongst them is the keen interest, and confidence, in their education system felt by the overwhelming majority of Scots. One important 
consequence of this is the significant measure of community of interest felt between teachers, parents and others. Another is a strong expectation on the part of a range of stakeholders - parents, churches, business and commerce and other community groups, as well as teachers - that they all will, as a matter of right, participate in the process of debate about policy development and change. Important, too, has been the powerful role played by teachers, and teachers' associations, in the processes of educational development. Through their local authorities and schools, they expect to be involved - indeed, they recognise their role as the main engine-room of the improvement process. Finally, the role played by central bodies and individuals in positions of national leadership is significant Such key players would claim to take care to go with the grain of public and professional expectations, rather than against it. There is probably a strong element of truth in this assertion, though perhaps not as much as is claimed. Above all, these various participants, while frequently in conflict, have never become ideologically disengaged from each other, and the protagonists in the debate have always felt it their obligation to take account of the critiques mounted by their opponents, whether professional or political.

Thus, the national processes for curriculum change and development in Scotland might be characteristically described as widespread and vigorous debate, accompanied by an earnest search for partnership and consensus. The size of the country -5 million people, 405 secondary and 2,500 primary schools - has undoubtedly enabled this process; nevertheless, it is difficult to avoid recognising, in its nature, a reflection of other aspects of national culture. It would be quite misleading to claim that in these arrangements Scotland has a democratic process for development, in the parliamentary sense-actually, it may be better and more effective than that. If, however, Scotland has been able to retain and develop quality within its schools and its education system, it is in part at least due to the fact that our modus vivendi has enabled us to avoid some of the sillier educational over-indulgences, and consequent hysterical overreactions, seen elsewhere.

Of course, a commitment to the principle of consultation and involvement as a human value is only part of the reason for this state of affairs. There is also on the part of those in positions of leadership a clear-and very pragmatic, and Scottish-recognition that the nature of the processes of education are such that, if real improvement is to be sought, then all participants must understand and agree how it is to be brought about. In this case we do not have to make a virtue out of a necessity: the two already coincide. Thus, for reasons of both principle and praxis, the processes of improvement within the education system in Scotland can be said to have a distinctively Scottish flavour. If the outcome is not satisfactory to us, then it might fairly be said to be mostly our own fault. 


\section{NATIONAL IDENTITY UNDER THREAT?}

I suppose that no contemporary discussion of national identity and a national curriculum could be complete without at least a reference to the processes of increasing internationalisation - the feared global homogenisation of culture, and thus identity. This process is seen by many, particularly in some other parts of the United Kingdom, as a threat. It will be evident from this chapter that I do not share that view. My own belief is that, no matter what happens to the political system within the United Kingdom or within Europe, an inexorable consequence of developments in the media and in communications will be to encourage in people a sense of identity simultaneously more local and more international. Already as a consequence of this process, Western Europe, at least, is, arguably, composed of peoples increasingly conscious of their own identity in a way which is at the same time respectful of that of others-we are learning to value our differences. I see the patterns of school provision and curricula reflecting these patterns of distinctiveness in a positive and inclusive way. And that is perfectly congruent with the nature and purpose of education. For it is the task of schools not only to preserve the past, but to enrich the future.

\section{REFERENCES}

Harrison, C.E. (1994) in Briefings for the National Commission on Education, London: Paul Hamlyn Foundation.

Hutton, W. (1995) The State We're In, London: Vintage.

Marshall, G. (1992) Presbyteries and Profits, Edinburgh: Edinburgh University Press. New History of Scotland series (1992), Edinburgh: Edinburgh University.

Porter, M. (1990) The Competitive Advantage of Nations, London: Macmillan.

Scott, P. (1993) A Concise Cultural History of Scotland, Edinburgh: Mainstream.

SED (1977) The Structure of the Curriculum in the Third and Fourth Years of the Scottish Secondary School (the Munn Report), Edinburgh: HMSO.

Smout, T.C. (1987) A Century of the Scottish People, London: Fontana.

SOED (1992) Upper Secondary Education in Scotland: Report of the Committee to Review Curriculum and Examinations in the Fifth and Sixth Years of Secondary Education in Scotland (the Howie Report), Edinburgh: HMSO.

Walker, A.L. (1994) The Revival of the Democratic Intellect, Edinburgh: Polygon. 